\title{
ISOLATED DEGENERATIVE C1 SPINAL STENOSIS: CASE REPORT AND REVIEW OF THE LITERATURE
}

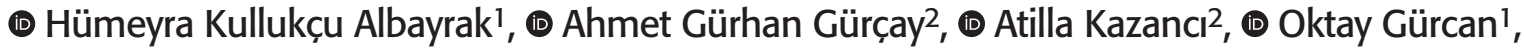 \\ (D) Mehmet Özgür Özateș 1
}

\author{
${ }^{1}$ Ankara City Hospital, Clinic of Neurosurgery, Ankara, Turkey \\ ${ }^{2}$ Yıldırım Beyazıt University Faculty of Medicine, Department of Neurosurgery, Ankara, Turkey
}

\begin{abstract}
Cervical spinal stenosis (CSS) is a pathology typically seen in males over the age of 65 years, at C5-6 and C6-7 distances, often due to a decrease in the cervical canal diameter, resulting from the degenerative process and the formation of a secondary neural compression. Although degeneration of the cervical spinal elements is the primary pathologic lesion in CSS, secondary compression of the spinal cord or spinal vascular structures is responsible for the emergence of myelopathy symptoms. Risk factors for normally localised CSS include increasing age, male gender, disc degeneration, loss of vertebral height due to ageing (with trauma or osteoporosis), posterior longitudinal ligament calcification and the presence of a congenital anomaly (Congenital CSC, Klippel-Feil Syndrome). Clinically, progressive myelopathic complaints are prominent depending on the degree of stenosis. Diagnosis is made by measuring the anteroposterior diameter of the cervical canal radiologically. Treatment is by surgical decompression with or without fusion, in patients having progressive clinical symptoms, with radiological evidence of a narrow canal and the existence of neurological compression. In this report, two patients without systemic/rheumatologic concomitant disease and congenital predisposing factors, who were operated for isolated C1 narrow canal were discussed with a review of the literature.

Keywords: Cervical spondylosis, Isolated C1 spinal stenosis, myelopathy
\end{abstract}

\section{INTRODUCTION}

Cervical spinal stenosis (CSS) is a progressive degenerative process which occurs as a result of fragmentation of intervertebral discs, decreased fluid content and collapse and ongoing degeneration of the spine ${ }^{(1)}$. Although degeneration of the cervical spinal elements is the primary pathologic lesion in the CSS, secondary compression of the spinal cord or spinal vascular structures is responsible for the emergence of myelopathy symptoms ${ }^{(1,2)}$. CSS is a natural result of ageing. It occurs in $10 \%$ and $95 \%$ of patients at 25 and 65 years, respectively ${ }^{(3)}$. Decreased sagittal diameter of the cervical canal is the main factor of the primary degenerative process in CSS. The clinical course is usually insidious and progressive. It often begins with stiffness and axial pain in the neck, progressing with pain and strength loss in the arms, numbness in the hands, loss of dexterity and sensation, gait imbalance, weakness and stiffness in the legs and rarely, sphincter control loss and urinary incontinence over time ${ }^{(4)}$. Diagnosis is made by the presence of progressive myelopathic complaints and when the anteriorposterior diameter of the cervical canal, which is normally 34.5 $\mathrm{mm}$ on average, is less than $10 \mathrm{~mm}$ on radiological examination.
In patients with radiologically diagnosed progressive deficit and myelopathic complaints, treatment includes surgical decompression with or without fusion. In this case report, two patients without systemic/rheumatologic concomitant disease and congenital predisposing factors, who were operated for isolated C1 spinal stenosis were discussed with a review of the literature.

\section{CASE REPORT}

Case 1: A 53-year-old male patient with no systemic concomitant disease was admitted to our clinic with increasing numbness in his hands and gait disturbance for the past 3 years. On neurological examination, the patient had no significant motor sensory deficits, Hoffman positivity was found on the right and his JOA score was 14 . The anteroposterior diameter of the cervical canal measured on preoperative cervical magnetic resonance imaging (MRI) was $6.1 \mathrm{~mm}$. The preoperative cervical computerised tomography (CT) and MRI of the patient showed thickening and hypertrophy of the posterior elements at the C1 level and increased cord signal in T2 sequences compatible with myelomalacia (Figure 1, 2). The patient was diagnosed

Address for Correspondence: Hümeyra Kullukçu Albayrak, Ankara City Hospital, Clinic of Neurosurgery, Ankara, Turkey E-mail: humeyrakullukcu@hotmail.com Received: 07.05.2020 Accepted: 07.05.2020

ORCID ID: orcid.org/0000-0003-0675-8288 
with C1 spondylotic canal and administered a C1 posterior decompression, C1-C2 instrumentation and fusion surgery. After 4 years of follow-up, no additional neurological deficit or radiological spondylotic canal was detected (Figure 3,4,5).

Case 2: A 67-year-old male patient with no systemic concomitant disease presented to our clinic with complaints of weakness in the hands, feeling of electric shock in the arms, inability to use the hands, inability to walk without support with increasing intensity for the past 2 years and urinary-faecal incontinence for the past 8 months. The patient's neurological examination revealed a marked decrease in fine motor abilities

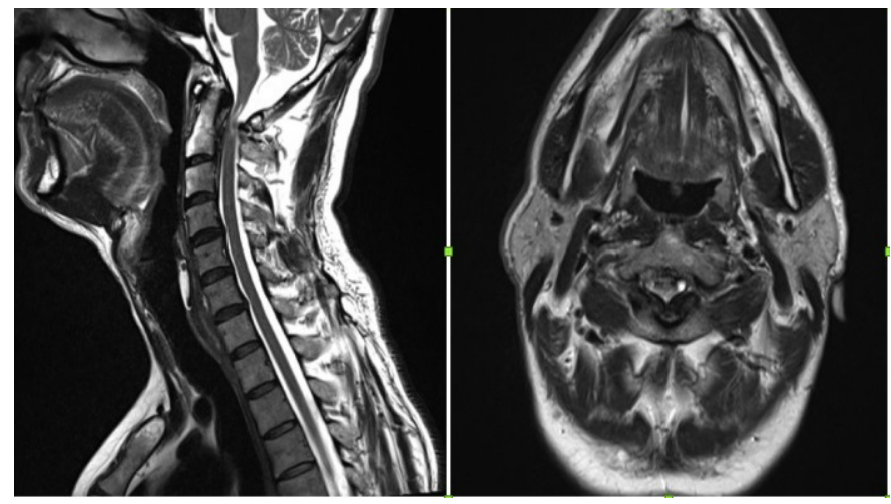

Figure 1. $1^{\text {st }}$ patient Pre-operative MRI MRI: Magnetic resonance imaging
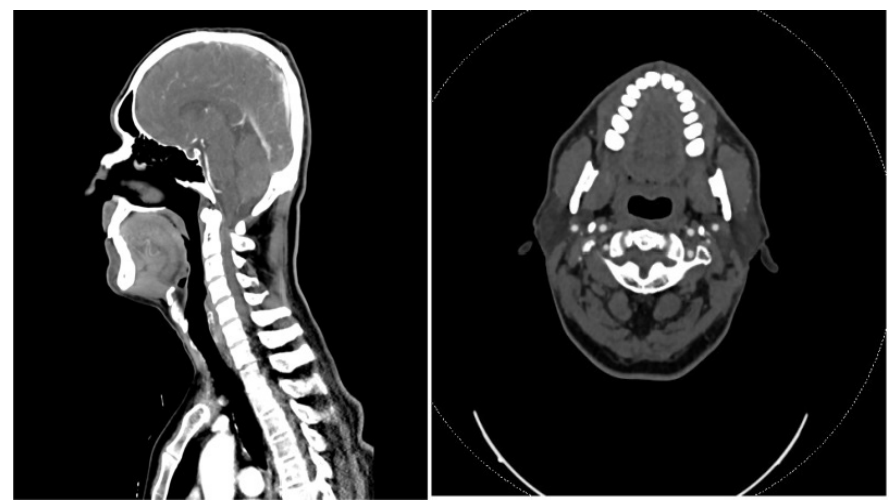

Figure 2. $1^{\text {st }}$ patient pre-operative CT $\mathrm{CT}$ : Computed tomography
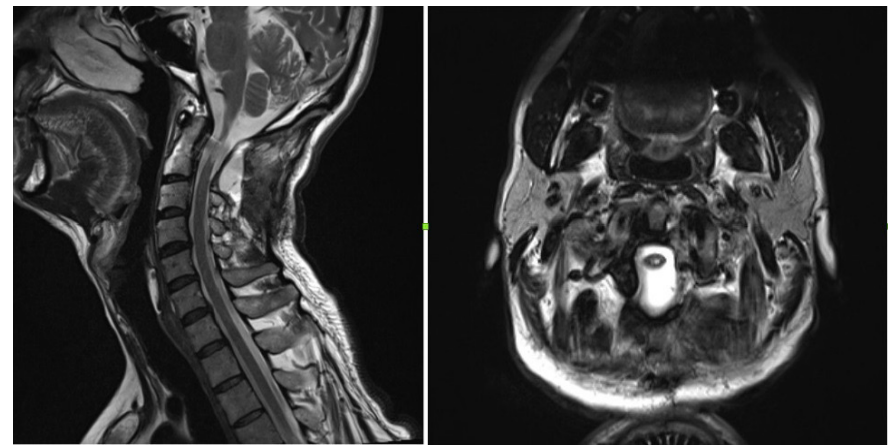

Figure 3. $1^{\text {st }}$ patient post-operative $4^{\text {th }}$ year MRI MRI: Magnetic resonance imaging on the right with a strength of $2 / 5$ in the right upper extremity, spasticity, Romberg positivity, hyperactivity in deep tendon reflexes, Hoffman and Lhermitte's signs and clonus positivity on the right; JOA score was 9. The anteroposterior diameter of the cervical canal was $7.2 \mathrm{~mm}$ on the patient's preoperative cervical MRI. The preoperative cervical MRI showed increased cord signal in $\mathrm{T} 2$ sequences compatible with myelomalacia at the C1-C2 level (Figure 6). The preoperative cervical CT of the patient did not show thickening and hypertrophy of the posterior elements at the $\mathrm{C} 1$ level (Figure 7). Upon diagnosis of the $\mathrm{C} 1$ spondylotic canal on the preoperative cervical MRI, $\mathrm{C} 1$ and $\mathrm{C} 2$ posterior decompression, C1-C2 instrumentation and fusion surgery were performed. After 8 years of follow-up, no additional neurological deficit or radiological spondylotic canal was detected (Figure 8, 9, 10).

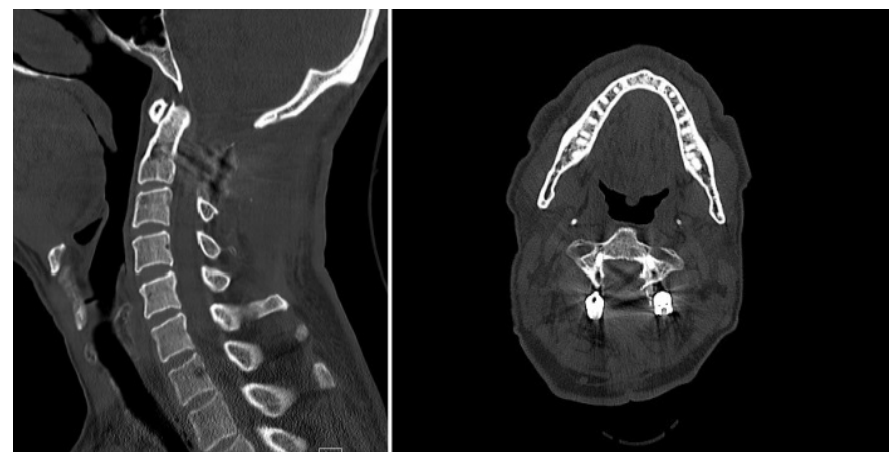

Figure 4. $1^{\text {st }}$ patient post-operative $4^{\text {th }}$ year CT $\mathrm{CT}$ : Computed tomography

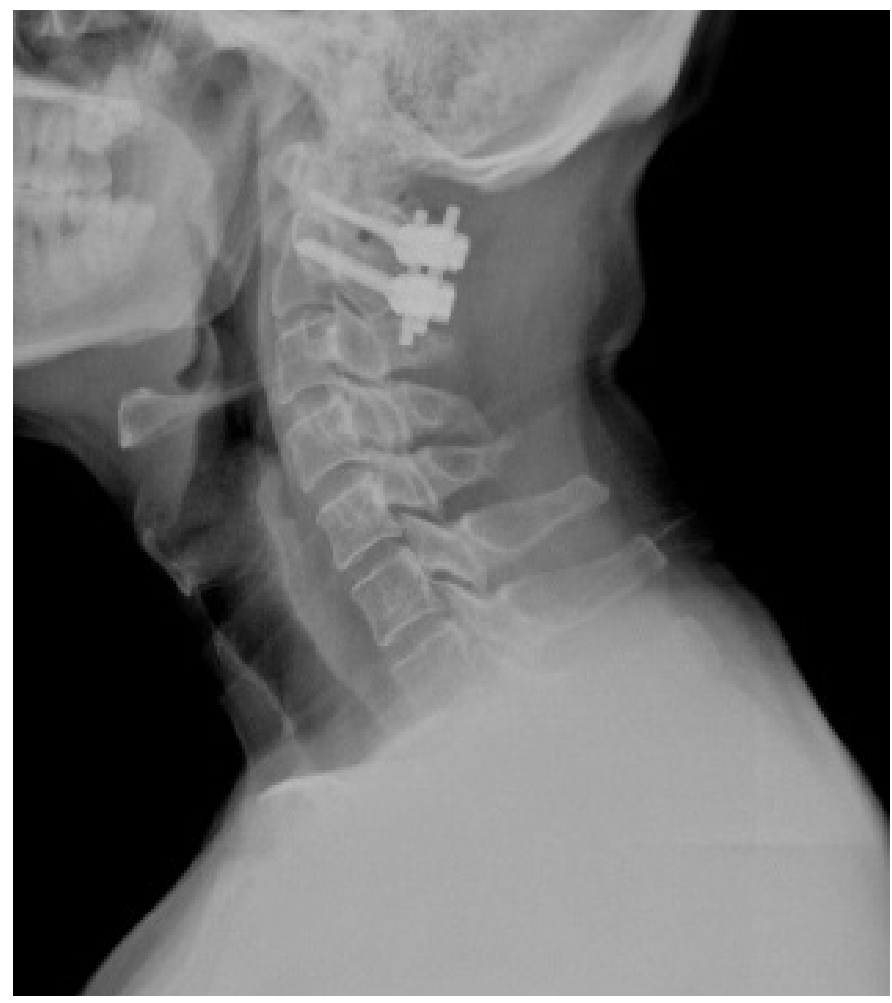

Figure $5.1^{\text {st }}$ patient post-operative $4^{\text {th }}$ year $X$-ray 


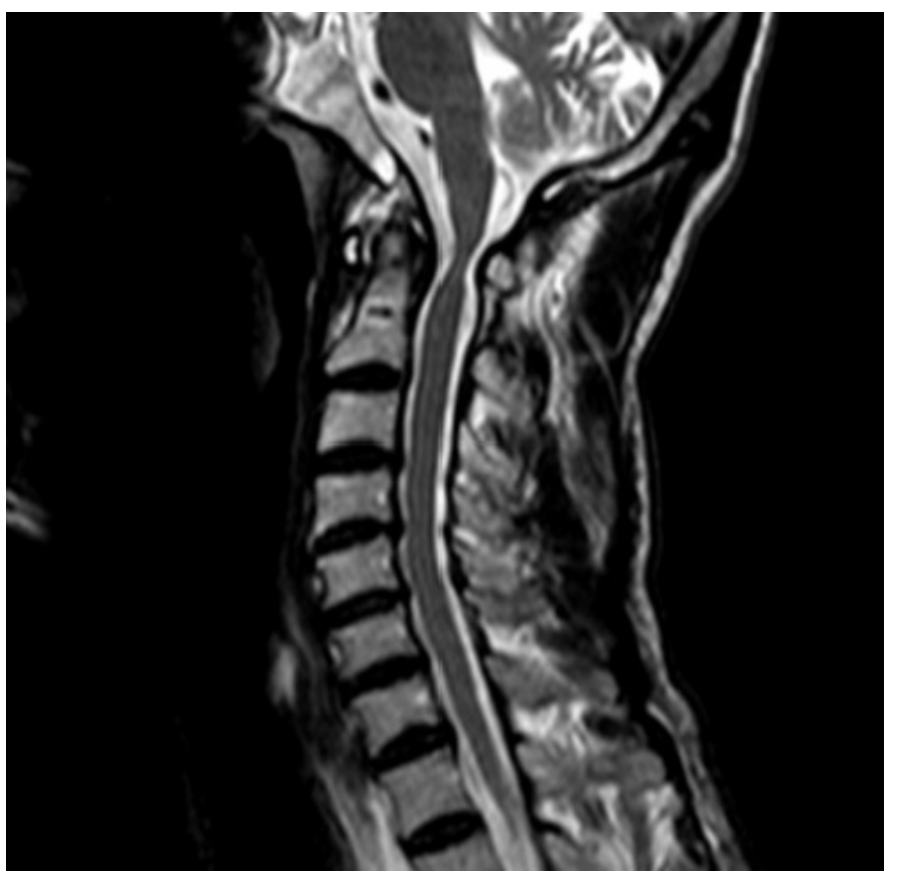

Figure 6. $2^{\text {nd }}$ patient pre-operative MRI MRI: Magnetic resonance imaging
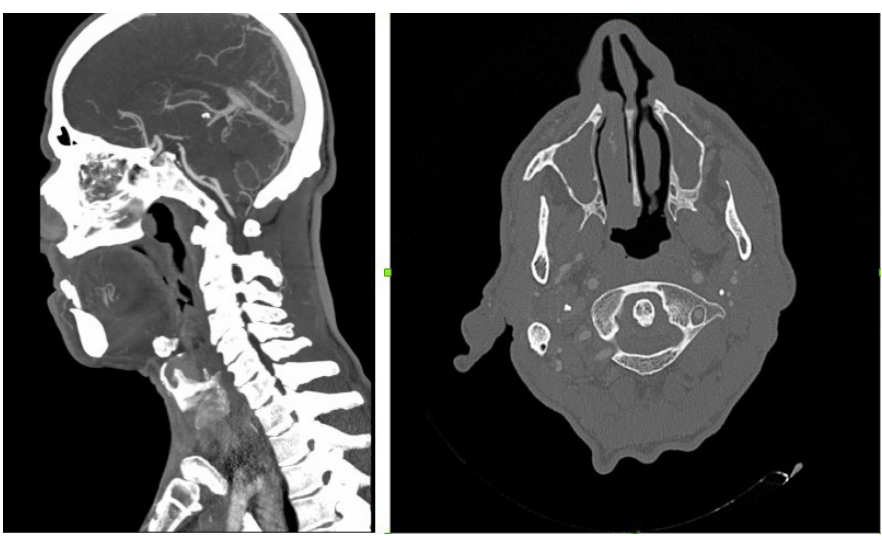

Figure 7. $2^{\text {nd }}$ patient pre-operative CT $\mathrm{CT}$ : Computed tomography

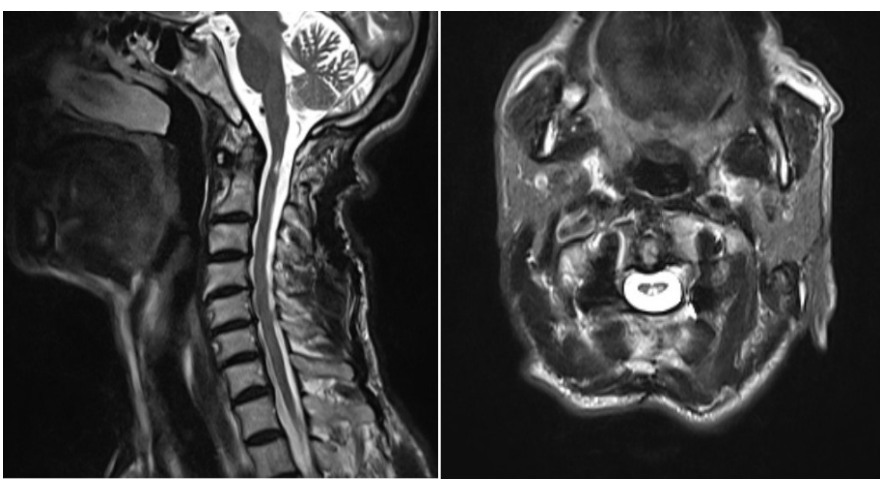

Figure 8. $2^{\text {nd }}$ patient post-operative $8^{\text {th }}$ year MRI MRI: Magnetic resonance imaging

\section{DISCUSSION}

The symptomatic degenerative process begins with the formation of osteophytes at the C5-6 and C6-7 distances, where movement is greater and therefore, CSS is most common ${ }^{(1,5)}$. Subsequently, C4-5 and C3-4 distances are typically affected ${ }^{(6)}$ After progressive degeneration, the spinal canal diameter, which normally varies between $17-18 \mathrm{~mm}$ from the C3-C7 vertebrae decreases and when it falls below $10 \mathrm{~mm}$ as defined in CSC, the clinical picture emerges after neuronal compression ${ }^{(7)}$. The mean anterior-posterior diameter of the cervical canal at the distance of C1-C2 is $34.5 \mathrm{~mm}$ and because of its rarity, there is no clear canal diameter defined in the literature for its clinical

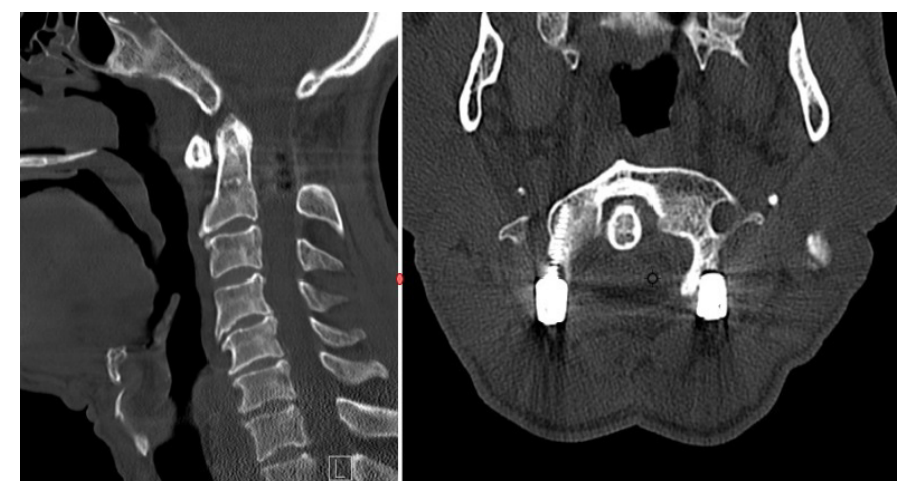

Figure 9. $2^{\text {nd }}$ patient post-operative $8^{\text {th }}$ year CT $\mathrm{CT}$ : Computed tomography

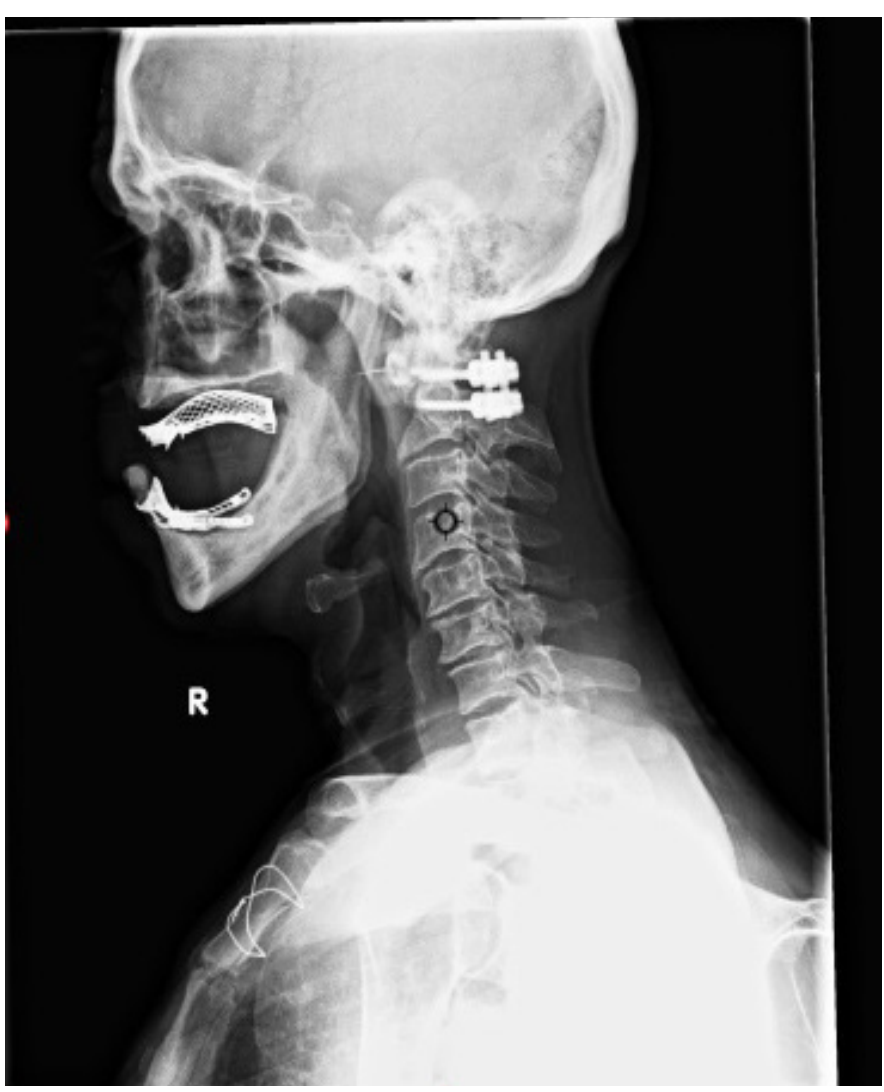

Figure $10.2^{\text {nd }}$ patient post-operative $8^{\text {th }}$ year $\mathrm{X}$-ray 
Table 1. Summary of the literature review on C1 stenosis

\begin{tabular}{|c|c|c|c|c|c|c|c|}
\hline & $\begin{array}{l}\text { Patient } \\
\text { number }\end{array}$ & $\begin{array}{l}\text { Age/ } \\
\text { Gender }\end{array}$ & Clinic & $\begin{array}{l}\text { Stenosis } \\
\text { level }\end{array}$ & Radiology & Treatment & Outcome \\
\hline $\begin{array}{l}\text { Komatsu } \\
\text { et al. }{ }^{(13)}\end{array}$ & 1 & $56 / \mathrm{M}$ & Cervical myelopathy & $\mathrm{C} 1$ & $\begin{array}{l}\text { Atlas hypoplasia with } \\
\text { segmental compression of the } \\
\text { spinal cord }\end{array}$ & $\begin{array}{l}\text { Decompressive } \\
\text { laminectomy of the atlas }\end{array}$ & $\begin{array}{l}\text { Remarkable } \\
\text { neurologic } \\
\text { recovery }\end{array}$ \\
\hline $\begin{array}{l}\text { Yamashita } \\
\text { et al.(14) }\end{array}$ & 1 & $73 / F$ & $\begin{array}{l}\text { Progressive cervical } \\
\text { myelopathy }\end{array}$ & $\mathrm{C} 1$ & $\begin{array}{l}\text { MRI: Hypoplasia of the atlas } \\
\text { associated with a retro- } \\
\text { odontoid pseudo-tumour } \\
\text { X-ray: Narrowing of the spinal } \\
\text { canal at the level of the atlas } \\
\text { and severe osteoarthrosis of } \\
\text { the atlantoaxial joint without } \\
\text { atlantoaxial subluxation }\end{array}$ & $\begin{array}{l}\text { Decompressive } \\
\text { laminectomy of the } \\
\text { atlas with posterior } \\
\text { occipitocervical fusion }\end{array}$ & $\begin{array}{l}\text { Remarkable } \\
\text { neurologic } \\
\text { recovery }\end{array}$ \\
\hline $\begin{array}{l}\text { Phan } \\
\text { et al. }{ }^{(15)}\end{array}$ & 2 & $\begin{array}{l}80 / \mathrm{M} \\
75 / \mathrm{M}\end{array}$ & $\begin{array}{l}\text { Progressive cervical } \\
\text { myelopathy }\end{array}$ & $\mathrm{C} 1$ & Hypoplastic posterior C1 arch & $\begin{array}{l}\text { Posterior decompression } \\
\text { with removal of both } \\
\text { posterior arches of } \mathrm{C} 1\end{array}$ & $\begin{array}{l}\text { Clinical } \\
\text { improvement }\end{array}$ \\
\hline $\begin{array}{l}\text { Okamoto } \\
\text { et al. }{ }^{(16)}\end{array}$ & 1 & $77 / \mathrm{M}$ & $\begin{array}{l}\text { 20-year history of } \\
\text { progressive gait } \\
\text { disturbance and } \\
\text { paresis of both the } \\
\text { upper and lower } \\
\text { extremities }\end{array}$ & $\mathrm{C} 1$ & $\begin{array}{l}\text { Severe canal stenosis at the } \\
\text { level of the atlas }\end{array}$ & $\begin{array}{l}\text { Resection of the posterior } \\
\text { arch of the atlas }\end{array}$ & $\begin{array}{l}\text { Clinical } \\
\text { improvement }\end{array}$ \\
\hline $\begin{array}{l}\text { Benitah } \\
\text { et al. }{ }^{(17)}\end{array}$ & 2 & $\begin{array}{l}78 / \mathrm{M} \\
41 / \mathrm{F}\end{array}$ & $\begin{array}{l}\text { Progressive cervical } \\
\text { myelopathy }\end{array}$ & $\mathrm{C} 1$ & $\begin{array}{l}1^{\text {st }} \text { patient: Unilateral } \\
\text { osteophytes on the left C1-2 } \\
\text { joint } \\
2^{\text {nd }} \text { patient: Congenital } \\
\text { hypertrophy of the laminae of } \\
\text { C1 and C2 }\end{array}$ & $\begin{array}{l}\text { Laminectomy and } \\
\text { ligamentum flavum } \\
\text { resection of the atlas and } \\
\text { axis }\end{array}$ & $\begin{array}{l}\text { Clinical } \\
\text { improvement }\end{array}$ \\
\hline $\begin{array}{l}\text { Nishikawa } \\
\text { et al. }{ }^{(18)}\end{array}$ & 3 & $\begin{array}{l}82 / \mathrm{M} \\
72 / \mathrm{M} \\
42 / \mathrm{F}\end{array}$ & Cervical myelopathy & $\mathrm{C} 1$ & $\begin{array}{l}\text { Congenital hypoplasia of the } \\
\text { atlas }\end{array}$ & Laminectomy of C1 & $\begin{array}{l}\text { Clinical } \\
\text { improvement }\end{array}$ \\
\hline $\begin{array}{l}\text { Urasaki } \\
\text { et al. }{ }^{(19)}\end{array}$ & 1 & $12 / \mathrm{M}$ & Cervical myelopathy & $\mathrm{C} 1$ & $\begin{array}{l}\text { Atlas hypoplasia with complete } \\
\text { posterior arch }\end{array}$ & $\begin{array}{l}\text { Decompressive } \\
\text { laminectomy of the atlas }\end{array}$ & $\begin{array}{l}\text { Clinical } \\
\text { improvement }\end{array}$ \\
\hline $\begin{array}{l}\text { Atasoy } \\
\text { et al. }\end{array}$ & 1 & $30 / \mathrm{M}$ & $\begin{array}{l}\text { Neck and left arm } \\
\text { pain }\end{array}$ & $\mathrm{C} 1$ & $\begin{array}{l}\text { MRI: Osodontoideum, marked } \\
\text { stenosis of the spinal canal at } \\
\text { the level of the atlas, with cord } \\
\text { compression and evidence of } \\
\text { myelopathy } \\
\text { CT: Hypoplasia of the posterior } \\
\text { arch }\end{array}$ & $\begin{array}{l}\text { Patient declined surgical } \\
\text { treatment }\end{array}$ & \\
\hline $\begin{array}{l}\text { Connor } \\
\text { et al. }\end{array}$ & 1 & 8/UNS & $\begin{array}{l}\text { Progressive upper } \\
\text { and lower limb } \\
\text { neurological } \\
\text { symptoms }\end{array}$ & $\mathrm{C} 1$ & $\begin{array}{l}\text { Medial posterior hemiarches of } \\
\text { a bifid C } 1 \text { to be in-turned and } \\
\text { compressing the cervical cord, } \\
\text { severe C } 1 \text { stenosis }\end{array}$ & $\begin{array}{l}\text { Laminectomy of the } \\
\text { posterior arch of C1 }\end{array}$ & $\begin{array}{l}\text { Clinical } \\
\text { improvement }\end{array}$ \\
\hline $\begin{array}{l}\text { Sato } \\
\text { et al. }\end{array}$ & 1 & $38 / \mathrm{M}$ & $\begin{array}{l}\text { Progressive cervical } \\
\text { myelopathy }\end{array}$ & $\mathrm{C} 1$ & $\begin{array}{l}\text { Atlas hypoplasia associated } \\
\text { with non-traumatic retro- } \\
\text { odontoid mass and hypertrophy } \\
\text { of the transverse ligament of } \\
\text { the atlas }\end{array}$ & $\begin{array}{l}\text { Decompressive } \\
\text { laminectomy of the atlas }\end{array}$ & $\begin{array}{l}\text { Clinical } \\
\text { improvement }\end{array}$ \\
\hline $\begin{array}{l}\text { Bokhari } \\
\text { and } \\
\text { Baeesa }^{(23)}\end{array}$ & 1 & $68 / F$ & $\begin{array}{l}\text { Progressive cervical } \\
\text { myelopathy }\end{array}$ & $\mathrm{C} 1$ & $\begin{array}{l}\text { Hypoplastic intact posterior } \\
\text { arch of } \mathrm{C} 1 \text { and concomitant } \\
\text { ossified transverse ligament }\end{array}$ & Laminectomy of C1 & $\begin{array}{l}\text { Clinical } \\
\text { improvement }\end{array}$ \\
\hline $\begin{array}{l}\text { Pascual- } \\
\text { Gallego } \\
\text { et al. }{ }^{(24)}\end{array}$ & 1 & $5 / M$ & $\begin{array}{l}\text { Down syndrome with } \\
\text { cervical myelopathy }\end{array}$ & $\mathrm{C} 1$ & $\begin{array}{l}\text { An anomaly of the atlas } \\
\text { leading to stenosis }\end{array}$ & Laminectomy of C1 & $\begin{array}{l}\text { Clinical } \\
\text { improvement }\end{array}$ \\
\hline $\begin{array}{l}\text { Nehete } \\
\text { et al. }{ }^{(25)}\end{array}$ & 20 & $\begin{array}{l}8 \text { Adults } \\
\text { (mean age } \\
22.85 \text { ) } \\
12 \\
\text { paediatric }\end{array}$ & $\begin{array}{l}\text { Syndromic } \\
\text { association with } \\
\text { cervical myelopathy }\end{array}$ & $\mathrm{C} 1$ & C1 arch stenosis & Laminectomy of C1 & $\begin{array}{l}\text { Improvement } \\
\text { in symptoms }\end{array}$ \\
\hline
\end{tabular}


formation in this distance. When the diameter of the spinal canal falls below $10 \mathrm{~mm}$ irrespective of the distance, an absolute narrow canal is considered and myelopathic complaints are observed. Consistent with the literature, both cases had severe myelopathic complaints secondary to decrease in the canal diameter, which were of greater intensity in the second case. When the affected cervical segments are examined in CSS, spondylotic changes occurring in the cervical spine alone, most commonly observed between the $\mathrm{C} 3$ and $\mathrm{C} 7$ cervical vertebrae, have a frequency of $15 \%$, whereas the frequency of spondylotic changes occurring at multiple levels is $60-85 \%{ }^{(8)}$. The presented cases had a rare C1 segment and single level involvement, without any predisposing factor and there was no case with similar features when the literature was reviewed.

Risk factors for normally localised CSS include increasing age, male gender, disc degeneration, loss of vertebral height due to ageing (with trauma or osteoporosis), posterior longitudinal ligament calcification and the presence of a congenital anomaly (Congenital CSC, Klippel-Feil Syndrome) ${ }^{(9,10)}$. Upper distance (C1-C2) cervical region involvement is typically seen in association with the presence of systemic connective tissue diseases such as rheumatoid arthritis. Spinal canal diameter is narrowed and myelopathic complaints develop following extension of the pannus formation, which occurs after recurrent acute synovitis attacks, from around the dens into the spinal canal $^{(11)}$. In post-mortem examinations conducted on these patients, the upper cervical region was involved at a rate of 59$80 \%$ and it was found that the cause of death was spinal cord compression in seven (63.6\%) of 11 cases $^{(12)}$.

We performed a literature search in the PubMed Database for "C1 Stenosis" and also cross-referenced articles. There are some predisposing factors of $\mathrm{C} 1$ spinal stenosis and Table 1 outlines the literature review of CSS diagnosed in the upper segment (C1). Isolated pure atlas hypoplasia is rare, while fissures and segmentation defects are relatively common. Arch anomalies of the atlas rarely causes compression, since they usually increase the canal space. Another anomaly that may be associated with hypoplasia and canal stenosis is an ossified transverse ligament, leading to chronic and progressive myelopathy. Some syndromic diseases that may be associated with hypoplasia of the atlas include Down syndrome, Turner syndrome, Morquio disease, ankylosing spondylitis, achondroplasia, gonadal dysgenesis and congenital spondyloepiphyseal dysplasia. A congenital malformation presents with clinical symptoms relatively later in life (as opposed to at birth or during childhood). Symptoms generally indicate superimposed age-related degenerative changes, such as ligamentum flavum buckling, pannus behind the dens or synovial cyst formation. Due to this reason and depending on the degree of congenital stenosis, the age of presentation of C1 stenosis may vary from small children to older adults.
When the predisposing risk factors for CSS were examined, there were no significant findings except for male gender and advanced age in the cases discussed. There was no congenital narrow canal or connective tissue disease.

In conclusion, new clinical and radiological narrow canal findings were not present after 4 and 8 years of follow-up. The cases are considered as rare cases due to both the development without the presence of predisposing factors and the distance involved being limited to the $\mathrm{C} 1$ level. As a result, it should be borne in mind that CSS can also be seen at the C1 level in the absence of predisposing factors, although rare.

\section{Ethics}

Informed Consent: Informed consent was obtained from the patient.

\section{Authorship Contributions}

Concept: H.K.A., A.K., O.G., Design: H.K.A., A.K., O.G., Data Collection or Processing: H.K.A., A.G.G., M.Ö.Ö., Analysis or Interpretation: H.K.A., A.G.G., M.Ö.Ö., Literature Search: H.K.A., A.K., M.Ö.Ö., O.G., Writing: H.K.A.

Conflict of Interest: No conflict of interest was declared by the authors.

Financial Disclosure: The authors declared that this study received no financial support.

\section{REFERENCES}

1. Shedid D, Benzel EC. Cervical spondylosis anatomy: pathophysiology and biomechanics. Neurosurgery. 2007;60:(Suppl 1):s7-13.

2. Baron EM, Young WF. Cervical spondylotic myelopathy: a brief review of its pathophysiology, clinical course and diagnosis. Neurosurgery. 2007; 60(Supp 1):35-41.

3. Garfin SR. Cervical degenerative disorders: Etiology, presentation and imaging studies. Instr Course Lect. 2000;49:335-8.

4. Chiles BW 3rd, Leonard MA, Choudhri HF, Cooper PR. Cervical spondylotic myelopathy: Patterns of neurological deficit and recovery after anterior cervical decompression. Neurosurgery. 1999;44:762-9.

5. Asgari S. Cervical spondylotic myelopathy, in Palmer JD (ed): Neurosurgery'96: Manuel of Neurosurgery. New York, Churchill Livingstone pp 1996: 750-4.

6. Baptiste DC, Fehlings MG. Pathophysiology of cervical myelopathy. Spine J. 2006; 6:190-7.

7. Bohlman HH, Emery SE. The pathophysiology of cervical spondylosis and myelopathy. Spine. 1998;13:843-6.

8. Mc.Cormack BM, Weinstein PR. Cervical spondylosis. West J Med. 1996; 165:43-51.

9. Batzdorf U. Complex cervical myelopaties. In: Frymoyer JW, ed. The Adult Spine. Principles and Practice. 2Nd ed. Philadelphia, Pa; Lippincot-Raven. 1997:1401-12.

10. Braakman R. Management of cervical spondylotic myelopathy and radiculopathy. J Neurol Neurosurg Psychiatr. 1994;54:257-63.

11. Casey ATH, Crockard HA, Bland JM, Stevens J, Moskovich R, Ransford AQ. Predictors of outcome in the nonambulent myelopathic patient with rheumatoid arthritis and atlantoaxial subluxation. A prospective study of 55 surgically treated Ranaeat class 3B patients. J Neurosurg. 1996;85:574-81.

12. Mikulowski P, Wollheim FA, Rotmil P, Olsen I. Sudden death in rheumatoid arthritis with atlantoaxial dislocation. Acta Med Scand. 1975;198:445-51. 
turkishspine

13. Komatsu Y, Shibata T, Yasuda S, Ona Y, Nose T. Atlas Hypoplasia as a Cause of High Cervical Myelopathy. Case Report. J Neurosurg. 1993;79:914-9.

14. Yamashita K, Aoki Y, Hiroshima K. Myelopathy Due to Hypoplasia of the Atlas.:A Case Report. Clin Orthop Relat Res. 1997;338:90-3.

15. Phan N, Marras C, Midha R, Rowed D. Cervical myelopathy caused by hypoplasia of the atlas: two case reports and review of the literature. Neurosurgery. 1998;43:629-33.

16. Okamoto K, Sumi M, Ikeda M, Sawamura S, Kataoka O. A Case of Cervical Myelopathy With Developmental Canal Stenosis at the Level of the Atlas. A Case Report Kobe J Med Sci 1998; 44(3),135-40.

17. Benitah $S$, Raftopoulos $C$, Balériaux $D$, et al. Upper cervical spinal cord compression due to bony stenosis of the spinal canal. Neuroradiology. 1994;36:231-3.

18. Nishikawa K, Ludwig SC, Colón RJ, Fujimoto Y, Heller JG. Cervical myelopathy and congenital stenosis from hypoplasia of the atlas: report of three cases and literature review. Spine (Phila Pa 1976). 2001;26:E80-6.

19. Urasaki E, Yasukouchi H, Yokota A. Atlas Hypoplasia Manifesting as Myelopathy in a Child: Case Report. Neurol Med Chir. 2001;41:160-2.
20. Atasoy C, Fitoz S, Karan B, Erden I, Akyar S. A rare cause of cervical spinal stenosis: posterior arch hypoplasia in a bipartite atlas. Neuroradiology. 2002;44:253-5.

21. Connor SE, Chandler C, Robinson S, Jarosz JM. Congenital midline cleft of the posterior arch of atlas: a rare cause of symptomatic cervical canal stenosis. Eur Radiol. 2001;11:1766-9.

22. Sato K, Kubota T, Takeuchi H, Handa Y. Atlas Hypoplasia Associated With Non-Traumatic Retro-Odontoid Mass. Neurol Med Chir. 2006;46:202-5.

23. Bokhari R, Baeesa S. Atlas hypoplasia and ossification of the transverse atlantal ligament: a rare cause of cervical myelopathy. Case Rep Neurol Med. 2012;2012:893284.

24. Pascual-Gallego M, Budke M, Villarejo F. Spinal stenosis at the level of atlas in a boy with Down syndrome. A case report and literature review. Neurocirugia (Astur). 2014;25:29-32.

25. Nehete LS, Bhat DI, Gopalakrishnan MS, Shukla D, Konar S, Singh P, et al. Unusual cause of high cervical myelopathy-C1 arch stenosis. J Craniovertebr Junction Spine. 2018;9:37-43. 